
\title{
Radio-immunoassay of Inswin in Alloxanized
Non-Pregnant Ewes
}

M.A. Nostafa, S. and S.A. Abdel-Ariz

Biochemistry Depontment, Faculty of Vet. Medi. cine, Cairo University. *Biochemistry Department, Faculty of Medicine, Zagazig University ana Hadioisotope Depariment, Atomic Energy Eszablishment, Egypt.

\begin{abstract}
THE PRESENT work is devoted to study the effect of different doses of alloxan on carbohydrates metaholism as a reto changes in insulin level.

Sera from alloxanized non-pregnant ewes were analysed for the following attributes :

a) Insulin, b) blood gIucose, c) blood ketone bodies. d) Serum total lipids, and e) serum total cholesterol.
\end{abstract}

Alloxan diabetes has been reported to be more severe by increasing either the dose or the concentration of its solution (Reid et al., 1962). In the meantime, it was found that experimental alloxan diabetes demonstrated some effects on many biochemical constithents in the body as, blood glucose, serum total lipids, serum total cholesterol, blood ketone bodies and insulin. This work is conductmetabolism as affect of different doses of alloxan on carbohydrate glucose, total lipids, to the changes in insulin level in relation to ewes. The suitabilityolesterol and ketone bodies in non-pregnant non-pregnant ewes for the study of therm of the alloxan-diabetic ed in the light of these findings of the hypoinsulin state is evaluat-

\section{Matorial and Methods}

Twenty four non-pregnant cross-bred (Rahmani X Merino) ewes were used. Their body weight was (50 to $60 \mathrm{~kg}$ ) and age (3 years). Ewes were healthy and kept under hygienic condition and veterinary supervision. The ration (per head) was composed of dried berseem $1 \mathrm{~kg}$, manufactured balanced pressed ration* $1 \mathrm{~kg}$ and water was supplied ad-libitum.

\footnotetext{
* Produced by Cairo Company for Oils and Soaps.
} 
Alloxan mono-hydrate $10 \%$ in physiological saline was injected $1 / \mathrm{V}$ in ewes jugular vein. The ewes were fasted $24 \mathrm{hr}$ before injection. The experimental ewes were divided into 4 groups (each of six ewes) and injected with the alloxan solution, per $\mathrm{kg}$ body weight as follows :

Group I : received a dose of $20 \mathrm{mg}$.

Group II : received a dose of $40 \mathrm{mg}$.

Group III : received a dose of $20 \mathrm{mg}$ followed by :

a dose of $50 \mathrm{mg}$ after 23 days from the first dose.

Group IV : received a dose of $70 \mathrm{mg}$ as one dose.

The injected ewes were fasted $8 \mathrm{hr}$ before sampling. Through a period of 23 days following each injection blood for analysis were collected each other day. Blood samples were collected using sodium floride as an anticoagumant, for the determination of :

Blood glucose

The modified colorimetrical method of folin and Wu (Varley, 1969) was used.

Blood ketone bodies

Were estimated iodometrically by the method of Plakoff et al. (1953).

Serum samples were obtained after clotting of blood by centrifugation and kept on ice for analysis within few hours for the determination of :

Insulin

Serum total insulin was estimated by Radioimmunoassay technique as that modified by Megahed et al. (1976).

Tgypt. J. Anim. Prod. 21, No.'1 (1981) 


\section{Total lipids}

Serum total lipids were determined spectrocolorimetrically by the technique of Frings et al. (1970) while is based on the sulphophosphovanillin reaction.

\section{Total cholesterol}

Zake (1957) technique for spectrocolorimetric determination of serum total cholesterol depends upon the reaction of cholesterol with glacial acetic acid, sulphuric acid and ferric chloride.

Normal level (control group) were taken from non-pregnant ewes before alloxan injection (72 samples).

The data obtained were analysed statistically (Snedicor, 1956) for each variable showing the sample mean, the sample standard error of the mean ( $上$ S.E.), and for comparing between the data gained from control and the experimental groups the " $t$ " test was applied

\section{$R \oplus \mathbf{R} \mathbf{l}$ s}

Insulin

Table 1 shows that serum insulin levels in control group (predose) has a mean value of $36.11 \pm 98$ micro unit $/ \mathrm{ml}$, Figure 1 shows the level of insulin in the sera of the four groups. There is a rise in insulin level in the first day after alloxan injection. The much larger increase is that of the third group (117.00 + 3.00 micro unit $/ \mathrm{ml}$ ), than the first group $109.67 \pm 3.80$, the second $93.50 \pm 3.50$ and fourth group $87.00 \pm 8.54$. This rise is followed by a rapid decline to nearly the normal level on the fifth day from injection in groups IV and III, while in groups I and II show more prolonged period of hyper-insulinaemia and a slower decline to nearly the normal level but still some what higher $\$ 3.27$ \pm 2.42 in group I and $45.00 \pm 3.46$ microunit in group II on the 15 days from injection, while in groups III and IV the decline was below the normal level $15.10 \pm 3.15$ for group III and $18.06 \pm 3.51$ for group IV (Table 2) on the fifteenth day from injection followed by a gradual rise in insulin level in groups III and IV $(57.00 \pm 3.86$ and $92.50 \pm 6.5$ for groups II and IV respectively on the $33 \mathrm{rd}$ day from injection.

Egypt. J. Anim. Prod. 21, No. 1 (1981) 


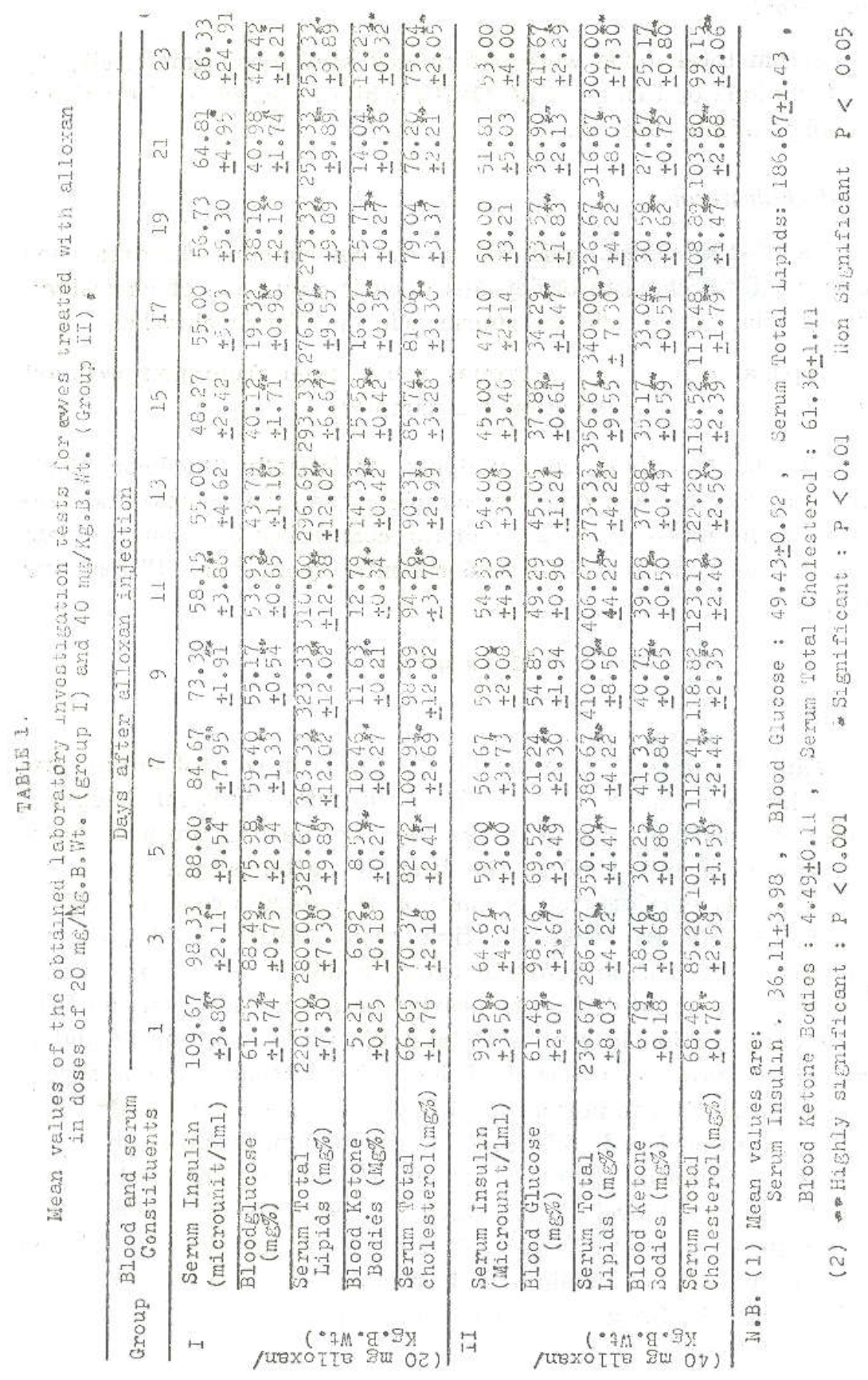

Egypt. J. Anim. Prod. 21, No. 1 (1981) 


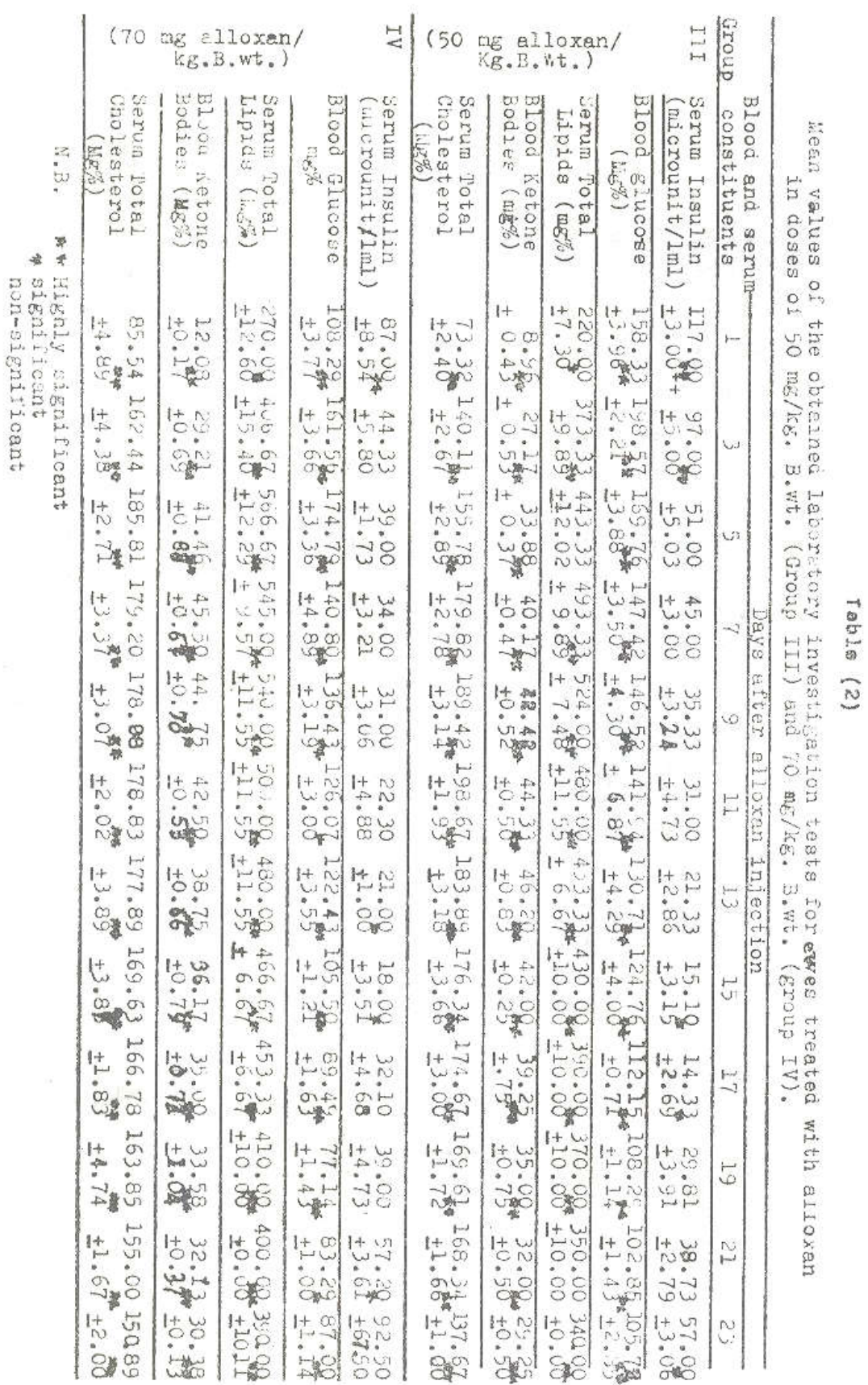

Egypt. J. Anim. Prod. 21, No. 1 (198: 


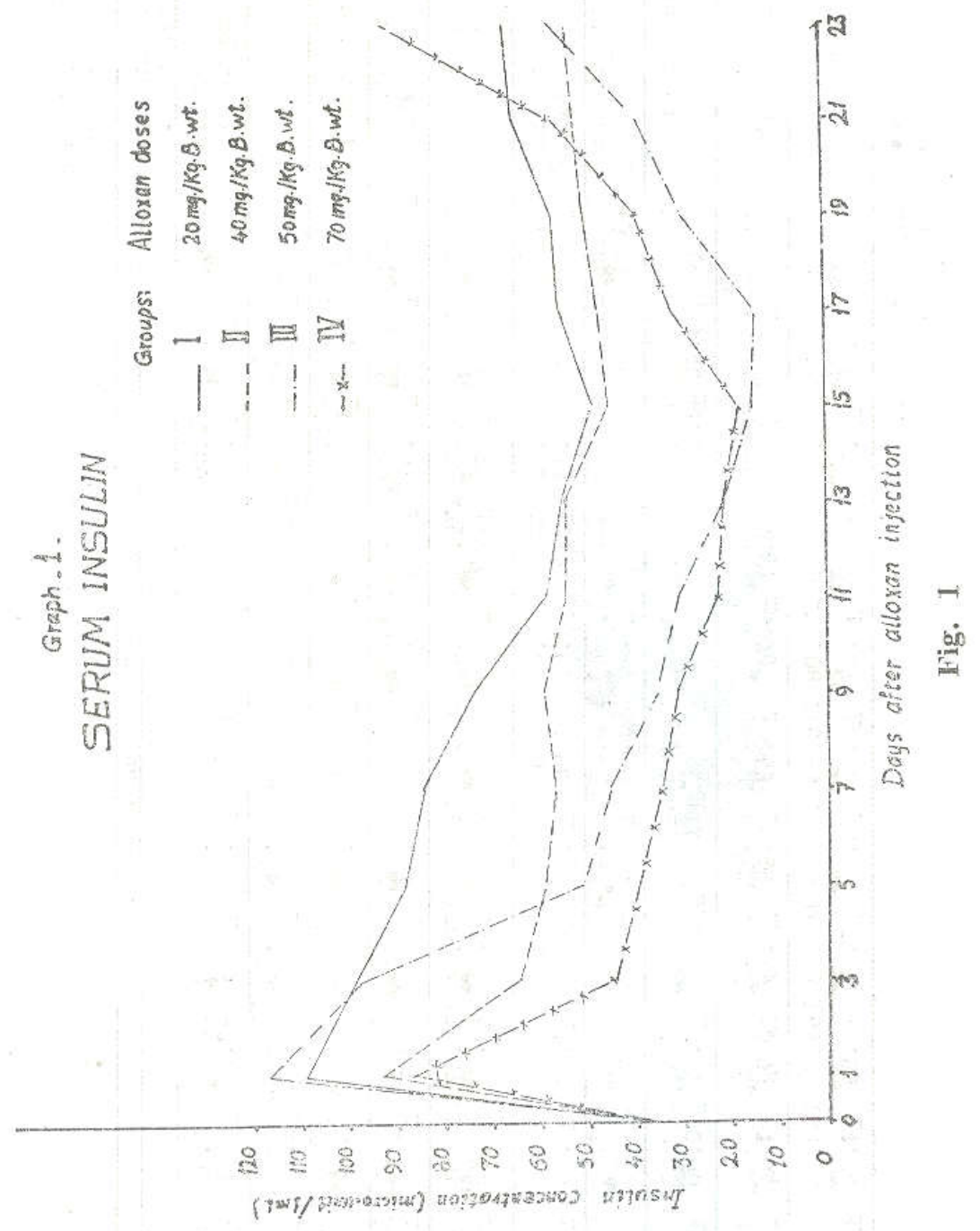

Figypt. J. Anim. Prod. 21, No. 1 (1981) 


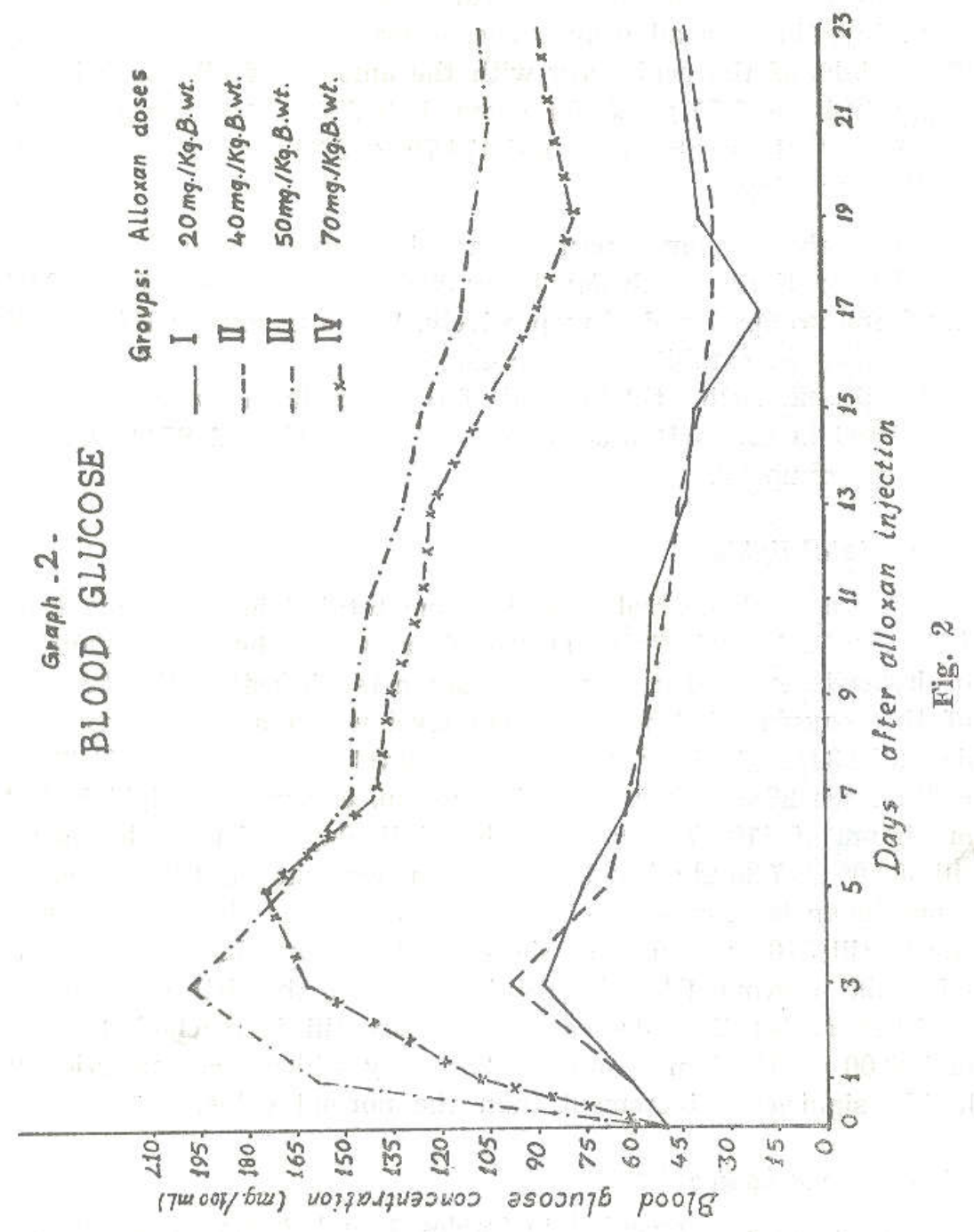

Egypt. J. Anim. Prod. 21, No. 1 (1981) 


\section{Glucose}

The results for glucose concentration are shown in Table 1 for groups I and II and Table 2 for groups III and IV. Figure 2 shows that glucose curve has a peak, this peak occurs on the $3 r d$ day from injection for all groups except group IV on the fifth day. The height of the peak vary with the amount of alloxan injected being $88.49 \pm 0.75 \mathrm{mg} \%$ for group I, $98.76 \pm 3.67$ for group II, $198.57 \pm 2.21$ for group III and $174.79 \pm 3.36 \mathrm{mg} \%$ for group IV on the firth day.

The glucose curve returned to the fasting level for groups $I$ and $I I$ on the eleventh day being $53.49 \pm 0.63$ and $49.29 \pm 0.96$ $\mathrm{mg} \%$ for groups I and II respectively. While in groups III and IV glucose curve exhibits more prolonged period of hyperglycemia and a slower decline till the end of the experiment where the glucose level in group II was $105.72 \pm 2.85 \mathrm{mg} \%$ and $87.00 \pm 1.14$ $\mathrm{mg} \%$ in group IV.

\section{Serum total lipids}

The normal (control group) serum total lipid had a mean of $186.67 \pm 1.43 \mathrm{mg} \%$ (Table 1). The four groups showed a condition of hyperlipaemia from the first day after injection till the end of the experiment. The maximum level was reached on the $7 \mathrm{th}$ day $(323.33 \pm 12.02 \mathrm{mg} \%)$ then the level decreased to $253.33 \pm$ 9.89 on the $23 r d$ day for the first group. Serum total lipid had a maximum of $410.00 \pm 8.56$ on the ninth day and then decreased till $300.00 \pm 7.30 \mathrm{mg} \%$ at the end of the experiment. Table 2 shows a maximum level of serum total lipid $524.00 \pm 7.48$ then declined slowly till $340.00 \pm 0.00$ at the end of the experiment for group III, while in group IV had a maxium level on the fifth day (566.67 $\pm 12.29 \mathrm{mg} \%$ ) then decreased gradually till it reached a value of $390.00 \pm 10.11 \mathrm{mg} \%$ on the $23 r d$ day which was statistically highly significant increment than the normal value.

\section{Blood ketone bodies}

The results represented in Tables 1 and 2 showed a case of hyperketonimea. In group I the concentration increased until it reached a maximum level of $16.67 \pm 0.35$ on the $17 t h$ day after injection and reached to $12.25 \pm 0.32$ on the $23 r d$ day. Group $I I$ had a

Egypt. J. Anim. Prod. 21, No. 1 (1981) 
maximum on the $7 t h$ day $(41.33 \pm 0.34 \mathrm{mg} \%)$ then decreased to $25.17 \pm 0.80 \mathrm{mg} \%$. Group III had a maximum of $46.20 \pm 0.83$ $\mathrm{mg} \%$ on the $13 \mathrm{t} h$ day and $29.25 \pm 0.50 \mathrm{mg} \%$ on the $23 r d$ day, and in group IV blood ketone bodies increased gradually from the first day $12.08 \pm 0.17 \mathrm{mg} \%$ till it reached a maximum value of $45.50 \pm$ $0.67 \mathrm{mg} \%$, on the $7 \mathrm{th}$ day then decreased till $30.38 \pm 0.13 \mathrm{mg} \%$ all the values are statistically highly significant increase from control group.

\section{Serum total cholesterol}

Table 1 shows that control group had a mean value of 61.36 $\pm 1.11 \mathrm{mg} \%$. The four experimental groups showed cases of hypercholesterolimea, through the experiment. In group 1 serum total cholesterol increased from the first day after injection till it reached a maximum level of $100.91 \pm 2.69 \mathrm{mg} \%$ on the seventh experimental day, then start to decrease gradually till it reached a value of $75.04 \pm 2.05 \mathrm{mg} \%$ at the end of the experimental which is statistically significantly higher than the control group. Group II serum total cholesterol has a mean value of $68.48 \pm 6.78 \mathrm{mg} \%$ in the first day after injection then increased till it reached a maximum level of $123.13 \pm 2.40 \mathrm{mg} \%$ on the $11 \mathrm{th}$ day started to decrease gradually till it reached a mean value of $99.15 \pm 2.06$ $\mathrm{mg} \%$ on the 23rd day after alloxan injection which is till statistically significantly higher than the control value at 0.001 level of probability.

\section{Dis cus ion}

In this study the experimental animals were made diabetics by destruction of the pancreatic is-lets tissue with alloxan, they may be regarded as representing a specific hypoinsulin state.

In general, Figures 1 and 2 show a rise in blood sugar level in the first week accompanied by a decrease in insulin level. Whatever showed in the results obtained for insulin, there is increase in the first day. The most likely explanation for this insulin increment in the first day may be due to delay conversion of proinsulin to insulin Megahed et al. (1977). This could be investigated by the rapid fall in total insulin at the $3 r d$ (Fig. 1) with the highly significant increase in glucose level at the same day (Fig. 2), as aloxan destroy selectively the pancreatic B-cells (Dunn et al., 1944). 
Concerning the effect of different doses of alloxan on insulin and glucose levels. Fig. 1 and 2 show that group $I$ in the first week following alloxan injection there is concomitant of insulin with glucose. In the second group the insulin decreased to the normal level which glucose increased, the third group represents a decriment of insulin to the normal level, with increase in glucose level which was more prominent in the $3 r d$ group with $20 \mathrm{mg}$ alloxan $23 \mathrm{rd}$ days before the second dose (50 $\mathrm{mg}$ of alloxan).

The second week is characterized by a slight decrease in insulin level but not insulin the normal range, in the first group, with a. decrease in glucose concentration to the normal level. The second group represented a significant decrease in insulin concentration than the normal with a slight decrease in blood glucose to the normal level. The $3 r d$ and 4 th groups showed a significant decrease in insulin concentration to below the normal level with a significant increase in blood glucose than the normal level.

The third week from alloxan injection demonstrated a slight increase in total insulin level up to the normal value for the 4 groups, accompanied by slight increase in glucose concentration up to the normal level for 1 st and 2 nd groups only. This may be due to regeneration of B-cells. In the $3 r d$ and $4 t h$ groups there were a highly significant increase which might be due to delay conversion of proinsulin to insulin as a result of the deleterious effect of doses of alloxan on B-cells. This probably may be due to alloxan which increased the B-cells permeability with marked reduction in the number of granules due to affinity of the B-cells membrane dithiol group to alloxan which explain the inhibition of insulin synthesis (Cooperstein et al., 1964). Moreover alloxan acts directly on the B-cell membrane. The binding of alloxan in its receptor site is followed by histological and biochemical changes, preventing the enzymatic synthesis of insulin as well as inhibition of its release (Korec, 1967 and Rerup, 1970).

From the aforementioned data it becomes evident that deficiency of insulin in alloxanized animals results in impaired transport of glucose into cells, which leads to a number of secondary metabolic effects, and the cardinal manifestations are hyperglycaemia, excessive production of ketone bodies from fatty acids.

Egypt. J. Anim. Prod. 21, No. 1 (1981) 
Cancerning serum total lipids, ketone bodies and total cholesterol, an increase was observed which was mostly highly significant in all groups after injection. As the utilization of glucose decreases in diabetic animals the utilization of fatty acids for energy increases. The fatty acids for kepatic utilization are obtained by mobilization from body fat depots. Mobilization increases as iasulin deficiency becomes more severe. In severe diabetic state excessive mobilization results in appearance of nextral fat in the circulation and lipaemia, occurs (Latner, 1975).

Concurrently with increased utilization of fatty acids a decrease in hepatic fatty acid synthesis occurs. The net effect is the production of acetoacetyl CoA in excess. The accumulated acetoacetyl CoA results in excessive production in ketone bodies and possibly cholesterol. Ketosis occurs when production of ketone bodies exceeds the capacity of the tissues for their disposal (Dickens et al., 1968).

$R \in f \in r \in n \in s$

Cooperstein, S.J., Watkins, D. and Lagarow, A. (1964) Wenner. Gren Int. symp 3, 389.

Dickens, F., Randle, P.J. and Whelcen, W.J. (1968) «Carbohydrate Retabolism and its Disorders». London and New York, Academic Press.

Dunn, đ.S., Duffy, E., Gilmov, M.K., Kirkpatrick, J. and MeLetchie, N.G.B. (1943-1944) ॠ. Physiol 103, 233.

Frings, Christopher S., and Dum Ralph, T. (1960) Am. d. Clin. Path. 55.

Korec, R. (1967) «Experimental diabetes mellitus in the ?

Latner A.I. (19\%5) "Clinical Biochemistry», 7th Ed. W.B. Saunders Company, London.

Megahed, Y.M., Abdel-Wahab, M.F., W-Shawarly, 互., Sadek, S. and Amer, M.S. (19\%6) Isotopen Praxis 12. Jahrgand. Heft 4.

Megahed, Y.M., Abdel-Wahab, M.F. and Sadek, S. (197\%) AinShams Međ. J. Vol. 28, No. 1, 7.

Egypt. J. Anim. Prod. 21, No. 1 (1981.) 
Plakoff, S.D. and Plakof, 1.C. (1953) Method of blood chemical analysis.

Reid, R.L., Hinks, N.T. and Mills, S.C. (1962) J. Endocrinol, 27, 1.

Berup, C. Clavs (1970) Pharmacol. Reviews, 22, 485.

Snedicor, W.G. (1956) «Statistical MTethods. 1st Ed. Iowa State Univ. Press. Ames. Iowa, U.S.A.

Varley, 11. (1969) «Practical Clinical Biochemistry», 4th Ed. William Heinemann-Medical Book Ltd. and Interscience Book Inc. London - New York.

Zalke, B. (195\%) Amer. J. Clin. Path. 2\%, 583.

$$
\begin{aligned}
& \text { قياس الانسولين بطريقة المنــــاءة الاشعاعية في النعســاج }
\end{aligned}
$$

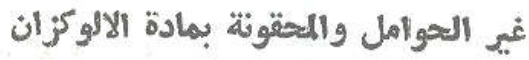

$$
\begin{aligned}
& \text { معبطفى عبد الفتاح مصطفى } 6 \text { شاكر طلخان الاعصر ، ياقوت مباهد وسامى } \\
& \text { عبد الهـيزيز } \\
& \text { كلية الطب البيطرى - جامعة القاهرة وكلية الطب ـ- جامعة الززقازيق }
\end{aligned}
$$

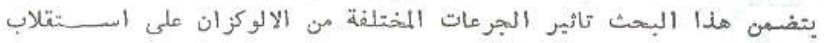

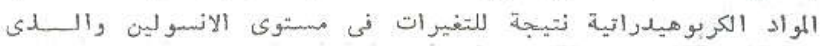

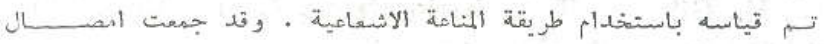

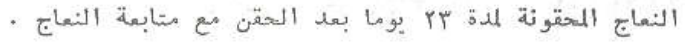

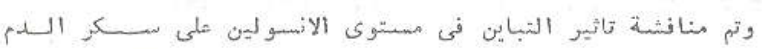

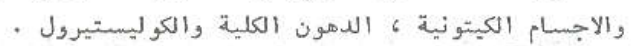

